\title{
Smoking History Not Available
}

National Cancer Institute

\section{Source}

National Cancer Institute. Smoking History Not Available. NCI Thesaurus. Code C156831.

An indication that the smoking history of an individual is unavailable. 